\title{
Feministic Images of Women in Shashi Deshpande's Fiction Roots and Shadows and The Binding Vine
}

\author{
Shilpa Sarkar \\ Research Scholar \\ Department of English \\ Guru Ghasidas University \\ Bilaspur, Chhattisgarh, India \\ sarkarshilpa16@gmail.com
}

\begin{abstract}
Shashi Deshpande is the most prolific writer among her contemporaries. Her writing reflects her image of middle class Indian woman. In most of her novels her protagonists are modern, well-educated and financially independent women. The main theme of her novels are problems of middle class women who were trapped between tradition and modernity. The protagonists always try to maintain their marriage in spite of the fact that they are mentally and physically tortured by their husbands. The objective of this study is to show the feminist perspective of Shashi Deshpande's women characters in her two novels Roots and Shadows and The Binding Vine. This study also aim to figure out how the women characters of these novels assert themselves.
\end{abstract}

Keywords: Protagonist, Tradition, Modernity, Marriage, Feminist Perspective. 
Shashi Deshpande is one of the leading women novelist in contemporary India. She won the Sahitya Akademi award for her novel, That Long Silence, and her work has been translated into many other foreign Shashi Deshpande considers herself as a feminist in personal life but not a feminist writer. "I write as a writer but am identified as a woman writer. I am nothing more than a novelist and a short- story writer but people seek more glorified titles to elevate you to stardom." "If critics and reviewers insist on calling me a woman writer, then 'man' should be prefixed to male writers as well". Her writing is a part of Indian literature with simple language to describe simple life, especially of middle class Indian society. Most of her novel reflect a realistic picture of contemporary middle class woman. Her protagonist are well educated modern women, but they are caught between tradition and modernity. These protagonists suffered since their childhood at the hands of men in their lives, either as a father or a brother, and after marriage from husbands or sons. In their childhood they were given second position by their parents and suffered from sex discrimination. In Indian society sons are given more importance than daughters. These girls were exhausted and not able to bear burden of second position in their family. In order to take revenge many of the protagonists of Shashi Deshpande married man of their choice. All the protagonists of her novel are educated and self sufficient. They are modern and unable to bear the burden of traditional Hindu custom of being a wife dominated by her husband. But they never walk out of their home. When these protagonists marry a man of their choice it is taken as a biggest challenge for the girl because she is told by her parents that this type of marriage doesn't last long and is advised not to come back home. So the protagonist suffered the domination of their husbands but they never returned home as it is the most shameful deed according to their parents. Unable to back out of marriage they bear the burden and suffer domination of their husband. They want to be remain as married woman because they 
take it as a prestige issue. The protagonist of Shashi Deshpande, Indu, Jaya, Suru, Sumi, Urmi, and Madhu suffered from great mental, physical, spiritual and sexual problems but they never walk out of their marriage. Women in Indian constitution are given equal rights to men but in their home while playing the role of wife she is not given equal rights which Shashi Deshpande portrays in her novels. The protagonist fight for their own rights but in a silent and a sober way. It is a cold opposition of the women in her novels but in the end they are hopeful for their future that they will be happy.

\section{Roots and Shadows}

In this novel, Shashi Deshpande presented a Maharashtrian Brahmin family. It was a joint family. This is the story of two generations. Akka was an old orthodox illiterate woman whereas Indu was a modern educated woman. The novel deals with women's main target that is how to live a happy married life. The novel begins with the marriage of Indu's cousin and Indu returned home after a gap of eleven years. Indu recalls warning of Akka before her marriage to Jayant “Such marriages never work. Different castes, different languages...it's all right for a while. Then they realise..." (Deshpande, Roots and Shadows 69). After her marriage Indu realized that her marriage is nothing more than a trap " that's what marriage is. A trap? Or a cage? May be the comic strip version of marriage... a cage with two trapped animals glaring hatred at each

other..." She was trapped between tradition and modernity. She was taught since her childhood that to be successful in society a woman should be weak " As a girl, they had hold me I must be meek and submissive. Why? I had asked. Because you are female.” (Deshpande, Roots 144). There were so many incidences in the novel which show Indu thinks about Jayant likes and dislikes. Indu herself notices this fact "when I look in the mirror, I think of Jayant, when I dress, 
I think of Jayant, when I undress, I think of him. Always what he wants. What he would like, What would please him. And I can't blame him. It's not he who has pressurized me into this. It's the way I want it to be. And one day I had thought...isn't there anything I want at all? Have I become fluid, with no shape, no form of my own? ( Deshpande, Roots 53). In this novel, real position of widows in our society is also shown. Widows were not treated equal to suhagans. Their head were shaven and they had to live a very simple life. Other women of the family were not allowed to take their meal before their husbands. Few things always disturbed Indu like women of her family were fasting for their husbands lives. Indu's husband was a highly dominating man and he forced Indu to do work with the editor whose work was completely unethical. In this state of confusion, she returned to her paternal home and there she indulges in self introspection and analysis her relationship with her husband.

Akka had an orthodox way of thinking and Indu was not at all happy with her behaviour but Indu's heart was full of pity when she heard the story of Akka. Narmada Atya told Indu that Akka suffered throughout her life. Akka was twelve when she got married. Her mother-in-law treated her very brutally but Akka never raised voice and remained silent. Her husband had a mistress but again she remained silent. When her husband was paralyzed she cared a lot for him. Shashi Deshpande also throws light on the problems associated with Indian marriage through the marriage of Mini, Indu's cousin. Mini does not remain unmarried so she got married to a person who was not at all suitable for her. In this novel Deshpande also shows the problems faced by the parents of a girl like caste system, gotras, dowry system and so on. In this novel Deshpande also shows the pathetic situation of mistress, who after the death of her man doesn't have the equal rights as married woman. 
Akka chose Indu as her heiress and gave her whole property to Indu. This was a remarkable change in the life of Indu that now she had the courage to take her own decisions. She decided to resign from her job and will publish her book. In this novel Shashi Deshpande tried to show Indu's weakness and her qualities. The novel ends with the hope that the heroine of the novel asserting herself as an individual.

In an article Authentic Female Characters in Shashi Deshpande novels, Monika Khurana comments:

"According to Shashi Deshpande, Indu in Roots and Shadows, and many women in her other novels had their roots in the same place. Shashi Deshpande herself says: Life as I saw it in a small town as a child, as a growing girl. Life as I saw it in Mumbai as a woman. And I saw it, the sharp, clean line dividing the world of men from the world of women. As a child I could cross over easily from one world into the other. Often I was the bridge. But as I grew up, I realized the bridge wasn't there anymore. I had ceased to be one myself. I was trapped into a world of my own. But, still, for some reason, outside the claustrophobic world of women." (1905)

The Binding Vine

Urmila, the protagonist of the novel The Binding Vine, is a middle class career-oriented woman and highly sensitive to the sufferings of other women. Urmila often referred to as Urmi, due to her high sensitivity towards the despair of other women she befriend Shakutai, whose daughter Kalpana was brutally raped. Shakutai belongs to the lower strata of society. It is this high sensitivity which makes her delve into the poems of Mira, her mother-in-law who was dead long before. 
This novel, The Binding Vine mainly revolves around the three woman Urmi, Shakutai and Mira. Urmi was trying to cope with the death of her daughter, Anu. All her relatives, friends tried to help her to come out of her grief. But all the efforts went into vain. S. Indira comments:

Instead of fighting her pain and sorrow, she holds on to it as she believes that to let go of that pain, to let it become a thing of the past would be a betrayal and would make her lose Anu completely. Like a masochist, she clings to her pain and allows her memories of Anu, every small incident to flood her with longing and a great sense of loss. (22)

Urmi was fighting with the memories of her one year old daughter and found it difficult and then she realized that forgetting is betrayal. "I must reject this memories, I have to conquer them. This is one battle I have to win if I am to go on living. And yet my victory will carry with it the taint of betrayal. To forget is to betray (Deshpande, The Binding Vine, 21). In this novel, there is a character named Mira who died at a very early age of twenty two and she was unhappy throughout her life due to marital rape committed by her husband. The same topic was taken in the novel The Dark Holds No Terror by Shashi Deshpande. Saru, the protagonist of the novel The Dark Holds No Terror, was assualted by her husband like an animal who was suffered from inferiority complex because of Saru's successful career.

During the time, when Urmi was completely involved in her daughter's memories, she came across a photograph of Mira, her mother-in-law, she was introduced there as "Kishore's mother, Kartik's grandmother” (Deshpande, Binding 42). Urmi was given an old trunk which was full of Mira's books and diaries. Going through the poems Urmi finds that Mira was the loving daughter of her father. He gifted Mira a book of poetry. Urmi realized that Mira had a keen desire to be recognised as a good poet. Since her childhood she was taught by her mother to play the role of an ideal wife. Mira always opposes her advice, who says "Never utter a 'no', 
submit and your life will be paradise" ( Deshpande, Binding 83). From the poetry of Mira, Urmi felt the pain and sufferings of Mira, which she had gone through. Her poems told the story of many mute unfortunate women's sufferings. Urmi translated the Kannad of poem written by Mira into English

"But tell me, friend, did Laxmi too twist brocade tassels round her fingers and tremble, fearing the coming of the dark-clouded, engulfing night?” (Deshpande,Binding, 66)

When Urmi meets Shakutai, another important character of this novel, she was grieving over the death of her daughter. But after knowing that Kalpana, daughter of Shakutai, was brutally raped, she was going through the rape case and decided to reopen the case. The story of Kalpana and Mira were very similar. Mira was raped after her marriage and Kalpana before her marriage but both of them went through similar pain. At first, Shakutai thought Kalpana met an accident but when doctor informed her that Kalpana had been raped. Shakutai denied the truth of her daughter's rape inorder to escape further problems. She says, "it's not true, you people are trying to blacken my daughter's name “ (Deshpande, Binding 58) and afterwards she burst into tears “... No, no, no tell him, tai, it’s not true, don’t tell anyone, I'll never be able to hold up my head again, who'll marry the girl, we're decent people, Doctor", she turns to him," don't tell the police". (Deshpande, Binding 58). This is the actual reason why so many women in our country don't want to report because of public shame. Urmi being a modern educated woman wanted to punish the culprit. But Shakutai was not convinced with Urmi. Shakutai sometimes praises her daughter and at the very next moment she started cursing her. She was so upset and disappointed 
with Kalpana's rape that she even wishes for her death. After so many hurdles, Urmi reopened the case and asked for new investigations. This matter soon gains public attention and finally investigations brings the rapist into light. Urmi fought for the injustice done towards Kalpana and ultimately won. According to Indira Nityandam:

The step forward, achieved in this novel, is the introduction of female bonding, the desire of one woman to help another less fortunate one. Urmila draws society's attention to the plight of the rape victim and is determined to get Mira's poems published. This was a positive development in the protagonist, for Sarita, Jaya and Indu were involved in fighting only their own battles." (66) 


\section{Works Cited}

Arora, Neena. Nayantara Sahgal and Dorris lessing- A Feminist Study in comparison. New Delhi: Prestige, 1991. Print.

Bhatnagar,P. "Indian Womanhood: Fights for freedom in Roots and Shadows." Indian Women Novelists Ed. R. K. Dhawan. New Delhi: Prestige, 1991 set I, vol v. Print.

Deshpande, Shashi. Roots and Shadows. Chennai: Orient Longman Pvt Ltd,1996.

Deshpande, Shashi. The Binding Vine. New Delhi: Penguin 1993.

Dhawan, R.K.Ed. Indian Women Novelists. New Delhi: Prestige Books. Set I Vol. I-IV. 1991.

Indira, S. “ A Bond or Burden?: A Study of Shashi Deshpande's The Binding Vine. Indian Women Novelists. Ed.R.K.Dhawan. New Delhi: Prestige, 1995,Set III, vol.6.Print.

Khurana, Monika. "uthentic Female Characters in the Novels of Shashi Deshpande. IJARIIE, Vol.2, 2016.

Narsimhan, Raji. Sensibility under Stress: Aspects of Indo-English Fiction. New Delhi: Ashajanak, 1976.

Nityandam, Indira. "Shashi Deshpande's The Binding Vine: Silence No More”. Indian Women Novelists set III, Vol.4. Print.

Ray, Mohit K and Ram Kundu. Eds. Studies in Women Writers in English. New Delhi: Atlantic Pub \& Dist. Set. I. Vol I-IV.2004.

Reddy, Sunita Y.S.A. Feminist Perspective of the Novels of Shashi Deshpande. New Delhi: Prestige Books, 2001.

Sandhu, Sarbajit K. The Image of Woman in the Novels of Shashi Deshpande. New Delhi: Prestige Books, 1991.

Sharma, Siddhartha. Shashi Deshpande's Novels A Feminist Study. New Delhi: Atlantic, 2005. 
Singh, Sushila. Ed. Feminism and Recent Fiction in English. New Delhi: Prestige, 1991.

Sandhu, Sarbjit K.The Image of Woman in the Novels of Shashi Deshpande. New Delhi: Prestige Books, 1991. 